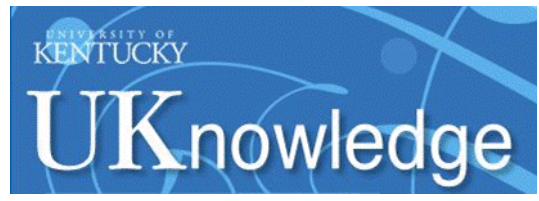

University of Kentucky UKnowledge

$6-2008$

\title{
Aluminum Bioavailability from Basic Sodium Aluminum Phosphate, an Approved Food Additive Emulsifying Agent, Incorporated in Cheese
}

Robert A. Yokel

University of Kentucky, ryokel@email.uky.edu

Clair L. Hicks

University of Kentucky, clhicks@uky.edu

Rebecca L. Florence

University of Kentucky, rlstep2@uky.edu

Right click to open a feedback form in a new tab to let us know how this document benefits you. Follow this and additional works at: https://uknowledge.uky.edu/ps_facpub

Part of the Pharmacy and Pharmaceutical Sciences Commons 


\section{Aluminum Bioavailability from Basic Sodium Aluminum Phosphate, an Approved Food Additive Emulsifying Agent, Incorporated in Cheese}

Digital Object Identifier (DOI)

http://dx.doi.org/10.1016/j.fct.2008.03.004

Notes/Citation Information

Published in Food and Chemical Toxicology, v. 46, no. 6, p. 2261-2266.

Copyright @ 2008 Elsevier Ltd. All rights reserved.

This manuscript version is made available under the CC-BY-NC-ND 4.0 license

http://creativecommons.org/licenses/by-nc-nd/4.0/ 
(C) 2008 Elsevier Ltd. All rights reserved.

This manuscript version is made available under the CC-BY-NC-ND 4.0 license http://creativecommons.org/licenses/by -nc-nd $/ 4.0 /$ 
Published in final edited form as:

Food Chem Toxicol. 2008 June ; 46(6): 2261-2266.

\title{
Aluminum bioavailability from basic sodium aluminum phosphate, an approved food additive emulsifying agent, incorporated in cheese
}

\author{
Robert A. Yokel ${ }^{\mathrm{a}, \mathrm{b}}$, Clair L. Hicks ${ }^{\mathrm{C}}$, and Rebecca L. Florence ${ }^{\mathrm{a}}$ \\ aDepartment of Pharmaceutical Sciences, College of Pharmacy, University of Kentucky Academic Medical \\ Center, 725 Rose Street, Lexington, KY 40536-0082, USA \\ bGraduate Center for Toxicology, University of Kentucky Academic Medical Center, Lexington, KY \\ 40536-0082, USA \\ cAnimal and Food Sciences Department, College of Agriculture, University of Kentucky, Lexington, KY \\ 40546-0215, USA
}

\begin{abstract}
Oral aluminum (Al) bioavailability from drinking water has been previously estimated, but there is little information on $\mathrm{Al}$ bioavailability from foods. It was suggested that oral $\mathrm{Al}$ bioavailability from drinking water is much greater than from foods. The objective was to further test this hypothesis. Oral Al bioavailability was determined in the rat from basic $\left[{ }^{26} \mathrm{Al}\right]$-sodium aluminum phosphate (basic SALP) in a process cheese. Consumption of $\sim 1 \mathrm{gm}$ cheese containing 1.5 or $3 \%$ basic SALP resulted in oral $\mathrm{Al}$ bioavailability $(\mathrm{F})$ of $\sim 0.1$ and $0.3 \%$, respectively, and time to maximum serum ${ }^{26} \mathrm{Al}$ concentration $\left(\mathrm{T}_{\max }\right.$ ) of 8 to $9 \mathrm{~h}$. These $\mathrm{Al}$ bioavailability results were intermediate to previously reported results from drinking water $(\mathrm{F} \sim 0.3 \%)$ and acidic-SALP incorporated into a biscuit $(\mathrm{F} \sim 0.1 \%)$, using the same methods. Considering the similar oral bioavailability of $\mathrm{Al}$ from food vs. water, and their contribution to the typical human's daily $\mathrm{Al}$ intake ( 95 and 1.5\%, respectively), these results suggest food contributes much more Al to systemic circulation, and potential Al body burden, than does drinking water. These results do not support the hypothesis that drinking water provides a disproportionate contribution to total $\mathrm{Al}$ absorbed from the gastrointestinal tract.
\end{abstract}

\section{Keywords}

Accelerator mass spectrometry; aluminum; atomic absorption spectrometry; basic sodium aluminum phosphate; food additive; oral bioavailability

\section{Introduction}

Aluminum (Al) is a toxicant to the central nervous, skeletal and hematopoietic systems (Krewski et al., 2007). The primary source of oral Al exposure in the U.S. for the typical human is foods, representing 95\% of daily oral intake; drinking water contributes $~ 1$ to $2 \%$ (WHO,

Corresponding author: Robert A. Yokel, Ph.D., 511C Pharmacy Building, 725 Rose Street, University of Kentucky Academic Medical Center, Lexington, KY40536-0082, phone: 859-257-4855, fax: 859-323-6886, e-mail: ryokel@email.uky.edu.

Publisher's Disclaimer: This is a PDF file of an unedited manuscript that has been accepted for publication. As a service to our customers we are providing this early version of the manuscript. The manuscript will undergo copyediting, typesetting, and review of the resulting proof before it is published in its final citable form. Please note that during the production process errors may be discovered which could affect the content, and all legal disclaimers that apply to the journal pertain. 
1997; ATSDR, 1999; Krewski et al., 2007). These typically provide a total of $\sim 4000$ to 9,000 $\mu \mathrm{g} \mathrm{Al} /$ day. Consumption of antacids can provide up to 5,000,000, inhalation from environmental and industrial air 4 to 20 and up to 25,000 , and antiperspirant use up to $~ 70,000$ $\mu \mathrm{g} /$ day. Injected $\mathrm{Al}$ in vaccines and allergy immunotherapy can provide 1 to 8 and 7 to $40 \mu \mathrm{g} /$ day, respectively, and probably complete absorption (Yokel and McNamara, 2001). Some people may have further $\mathrm{Al}$ exposures, e.g., occupational (Elinder et al., 1991), Alcontaminated dialysis fluid (Alfrey et al., 1976), alum instillation into a hemorrhaging urinary bladder (Phelps et al., 1999) and illicit drug abuse, including intravenous self-injection of methadone prepared in Al cookware (Friesen et al., 2006; Yong et al, 2006; Exley et al, 2007). Although tobacco contains considerable $\mathrm{Al}, \sim 500$ to $2000 \mu \mathrm{g} /$ cigarette, $<0.02$ to $0.075 \mu \mathrm{g}$ appeared in the smoke from one cigarette (Cogbill and Hobbs, 1957; Exley et al., 2006). Even if $100 \%$ bioavailable, when compared to oral $\mathrm{Al}$ intake of $5000 \mu \mathrm{g} / \mathrm{day}$ from diet that is $0.25 \%$ bioavailable delivering $12.5 \mu \mathrm{g}$ to systemic circulation, a cigarette would deliver only $\sim 0.4 \%$ as much. It was suggested that drinking water provides a disproportionate contribution to total $\mathrm{Al}$ absorbed from the gastrointestinal tract because it is largely uncomplexed in water, whereas organic ligands such as phytates and polyphenols in food were suggested to complex Al and inhibit its oral absorption (Martyn et al., 1989). This notion has been followed by $\geq 12$ epidemiological studies since 1989 assessing the association between $\mathrm{Al}$ in drinking water and cognitive impairment, dementia and Alzheimer's disease (AD) (Krewski et al., 2007). Many showed a significantly higher odds ratio for dementia among study subjects living in areas where the drinking water had a higher $\mathrm{Al}$ concentration. However, there is no evidence that drinking water is the major source of systemic Al for the typical person. The study in this report was aimed at testing this notion.

If $\mathrm{Al}$ bioavailability from water is not considerably greater than from food, studies assessing a putative link between $\mathrm{Al}$ in drinking water and $\mathrm{AD}$ might be misfocused, and studies investigating a possible association between $\mathrm{Al}$ in food and cognitive impairment, dementia and $\mathrm{AD}$ might be more relevant. There is only one published study assessing a putative link between dietary Al intake in food and AD (Rogers and Simon, 1999). In 23 matched sets of residents of a geriatric center with and without $\mathrm{AD}$, the adjusted odds ratio for several food groups, including baked goods and cheese, was elevated. However, due to the very small sample size, most results did not reach statistical significance.

Adult daily dietary $\mathrm{Al}$ intake in the U.K. and U.S. has been estimated to be 3.9 and 7 to $9 \mathrm{mg}$ (depending on age and sex), respectively (UK-MAFF, 1993; Pennington and Schoen, 1995). There have been at least 12 other estimates of adult dietary $\mathrm{Al}$ intake published in the past 10 years from other countries. Most reported equal or less daily $\mathrm{Al}$ intake than in the U.S. The lower daily $\mathrm{Al}$ intake in some countries, such as in Europe, has been attributed to less use of $\mathrm{Al}$ as a food additive (Müller et al., 1998).

Different food sources contribute variable amounts of $\mathrm{Al}$ to the human diet (Pennington, 1987; UK-MAFF, 1993; Lopez et al., 2002). Sodium aluminum phosphates (SALPs) are generally recognized as safe (GRAS) FDA-approved food additives that contribute the greatest amount of Al to the diet (Katz et al., 1984; Humphreys and Bolger, 1997; Saiyed and Yokel, 2005). Basic SALP is one of many "emulsifying salts" added to process cheese, cheese food and cheese spread which react with and change the protein of cheese to produce a smooth, uniform film around each fat droplet to prevent separation and bleeding of fat from the cheese. This produces a soft texture, easy melting characteristics and desirable slicing properties (Ellinger, 1972). Basic SALP is permitted by the FDA up to $3 \%$ in pasteurized process cheese (21CFR133.169), pasteurized process cheese food (21CFR133.173), and pasteurized process cheese spread (21CFR133.179). The FDA regulates basic SALP as an emulsifier that is GRAS (FASEB, 1975). Basic SALP is also permitted up to $3.5 \%$ in cheese in Canada (Food and Drugs Act - Food and Drug Regulations, Part B, Division 16; 
http://www.hc-sc.gc.ca/fn-an/alt_formats/hpfb-dgpsa/pdf/legislation/e_c-tables.pdf), as potassium aluminum silicate up to $10 \mathrm{~g} / \mathrm{kg}$ in Australia and New Zealand

(

http://www.foodstandards.gov.au/_srcfiles/FSC_Amend_Standard_1_2_4_Labelling_of_Ingred_v91.pdf\#search=\% ), but evidently not by the E.U. or U.K., although other Al-containing compounds are permitted in cheese, up to $10 \mathrm{~g} / \mathrm{kg}$ (E 554, E 555, E 556 and E 559)

(http://ec.europa.eu/food/fs/sfp/addit_flavor/flav11_en.pdf

http://ec.europa.eu/food/fs/sc/scf/reports/scf_reports_40.pdf). Studies of the Al content of unprocessed cheese generally reported $<10 \mathrm{mg} \mathrm{Al} / \mathrm{kg}$ (Delves et al., 1989; Schenk et al., 1989; Müller et al., 1998; Dolan and Capar, 2002). In contrast, some process cheeses (often marketed as sliced, American) were reported to contain 695 (Gormican, 1970), 411 (Pennington, 1989), 320 (Pennington and Schoen, 1995), 1440 (Greger, 1985), and $470 \mathrm{mg}$ $\mathrm{Al} / \mathrm{kg}$ (Saiyed and Yokel, 2005). The cheese of frozen pizzas that contained basic SALP was reported to contain up to $\sim 750 \mathrm{mg} \mathrm{Al} / \mathrm{kg}$, whereas ready-to-eat restaurant pizza cheese had < $10 \mathrm{mg} \mathrm{Al} / \mathrm{kg}$ (Saiyed and Yokel, 2005). Basic SALP $\left(\mathrm{Na}_{8} \mathrm{Al}_{2}\left(\mathrm{OH}_{2}\right)\left((\mathrm{PO})_{4}\right)_{4}\right)$ has a 4:1:2 ratio of Na:Al:P. It is 10\% Al.

Concern about the safety of the addition of $\mathrm{Al}$ in foods was expressed long ago (Gies, 1911) and again recently. Department of the Planet Earth (a non-profit NGO) petitioned the FDA in 2005 to rescind the GRAS status for Al-based food additives (http://www.deptplanetearth.com/aboutus.html). A Joint FAO (Food and Agriculture Organization of the UN)/WHO Expert Committee on Food Additives established a revised provisional tolerable weekly intake (PTWI) for all Al compounds in foods, including additives, of $1 \mathrm{mg} / \mathrm{kg} / \mathrm{bw}$. The Expert Committee noted the potential for Al to effect the reproductive and developing nervous system at lower doses than those used to establish the previous PTWI of $7 \mathrm{mg} / \mathrm{kg} / \mathrm{bw}$ (FAO/WHO, 2006). The Committee commented on the "probable lower bioavailability of the less soluble Al compounds present in food" and that the PTWI was likely to be exceeded by some population groups, particularly children, who regularly consume foods containing $\mathrm{Al}$ additives.

To better understand the relative contribution of food and water to human $\mathrm{Al}$ intake, it has been noted that research needs to be conducted to more accurately determine the oral bioavailability of $\mathrm{Al}$ from the typical diet (Personal communication from Amal M. Mahfouz, US EPA). Oral bioavailability (fractional absorption) is the amount absorbed compared to the amount administered. For Al, systemic bioavailability, the fraction that reaches systemic circulation from which it has access to the target organs of its toxicity, is most relevant.

Several studies have estimated oral Al bioavailability under conditions that model Al consumption in drinking water. Oral Al bioavailability from alum-treated water obtained from a municipal water treatment facility was estimated to be $0.36 \%$ in a study of 21 humans (Stauber et al., 1999). Two studies in humans that utilized ${ }^{26} \mathrm{Al}$ but only two subjects each, therefore providing limited confidence in the results, estimated oral Al bioavailability to be 0.1 and $0.22 \%$, respectively (Hohl et al., 1994; Priest et al., 1998). The above studies estimated oral $\mathrm{Al}$ absorption based on urinary $\mathrm{Al}$ excretion. However, not all absorbed $\mathrm{Al}$ appears in the urine, which accounts for $\sim 98 \%$ of excreted Al, or the bile, which accounts for most of the other $2 \%$. Some absorbed $\mathrm{Al}$ is retained. Secondly, if $\mathrm{Al}$ in the urine is used as an endpoint for absorption, the experimenter would have to continue to determine this endpoint until sure that all had been eliminated. There are a few reports where the amount of $\mathrm{Al}$ in the urine was corrected for these 2 factors (not all absorbed $\mathrm{Al}$ appears in the urine and the study was not conducted long enough to collect all excreted Al). Stauber et al. (1999) multiplied the amount of Al that appeared in the urine in the 24 hours after oral $\mathrm{Al}$ consumption by 2.2, to correct for partial $\mathrm{Al}$ elimination (only $72 \%$ of intravenously injected $\mathrm{Al}$ was found in the urine after 7 days (Talbot et al., 1995 ) and only 62 to $63 \%$ of the $\mathrm{Al}$ in the urine recovered in 7 days was found in the first day 
(Priest, 1993)). Stauber et al only collected urine for 24 hours. They did not correct for absorbed $\mathrm{Al}$ that was retained. The large correction factor reduces confidence in the accuracy of the reported oral bioavailability. Hohl et al. (1994) took into consideration that only about $80 \%$ of injected $\mathrm{Al}$ was found in the urine after 10 days and commented that the amount of $\mathrm{Al}$ excreted in the urine after their 4 days of collection was probably not great. They provided an estimate of the percentage of $\mathrm{Al}$ absorbed as $0.1 \%$, not presenting this as a precise value. In two studies that used the methods employed in the present report oral Al bioavailability in the rat averaged $0.28 \%$ and $0.29 \%$ (Yokel et al., 2001; Zhou and Yokel, 2006).

The bioavailability of hydrophilic substances that are not well absorbed can be determined by comparing the areas under the concentration $\times$ time curve (AUC) for the test substance given po and iv. This approach was used in the only study reported to date that estimated oral $\mathrm{Al}$ bioavailability from a specific food product. In that study, oral Al bioavailability in rats that ate $\sim 1 \mathrm{gm}$ of biscuit containing [ $\left.{ }^{26} \mathrm{Al}\right]$-labeled acidic SALP averaged $\sim 0.12 \%$ (Yokel and Florence, 2006). This approach was used in the present study in which the po dose was given as ${ }^{26} \mathrm{Al}$ and the iv dose as ${ }^{27} \mathrm{Al}$ to the same subject at the same time. Compared to an experimental design where a rat receives the two doses at different times, this method reduces variability by concurrently determining the AUCs from the po and iv doses in the rat. To determine the oral bioavailability of $\mathrm{Al}$ from basic SALP in a process cheese, $\left[{ }^{26} \mathrm{Al}\right]$-containing basic SALP was prepared and incorporated into a process cheese that was presented to rats for their consumption. Blood was repeatedly obtained from the rats in which ${ }^{26} \mathrm{Al}$ and total $\mathrm{Al}$ (essentially ${ }^{27} \mathrm{Al}$ ) were analyzed by accelerator mass spectrometry (AMS) and electrothermal atomic absorption spectrometry (ETAAS), respectively. The absence of significant ${ }^{26} \mathrm{Al}$ in the environment or in normal biological organisms avoids the interference of endogenous $\mathrm{Al}$ in studies of $\mathrm{Al}$ pharmacokinetics. When $4 \mathrm{mg}$ of ${ }^{27} \mathrm{Al}$ is added to ${ }^{26} \mathrm{Al}$-containing samples to establish the ${ }^{27} \mathrm{Al}$ concentration, as in the present study, AMS can measure the ${ }^{26} \mathrm{Al}:{ }^{27} \mathrm{Al}$ ratio with a detection limit of $\sim 10^{-14}\left(\sim 4 \times 10^{-17} \mathrm{~g}\right.$ of $\left.{ }^{26} \mathrm{Al}\right)$ or $\sim 1,000,000$ atoms. This enables the conduct of pharmacokinetic studies of $\mathrm{Al}$ at physiological concentrations, as conducted herein. In addition to oral bioavailability, two other standard pharmacokinetic parameters, the time to maximum serum ${ }^{26} \mathrm{Al}$ concentration of $\left(\mathrm{T}_{\max }\right)$ and the maximum serum ${ }^{26} \mathrm{Al}$ concentration of $\left(\mathrm{C}_{\max }\right)$, were determined (Bauer, 2006). These methods enabled us to address the objectives of the present study: to determine the oral bioavailability of $\mathrm{Al}$ from processed cheese that contains basic SALP, at a concentration relevant to its use in cheese, and to determine standard pharmacokinetic parameters of the absorbed Al.

\section{Methods}

\section{Materials}

Details of the preparation and characterization of the basic SALP containing ${ }^{26} \mathrm{Al}$ (basic ${ }^{26} \mathrm{Al}$ SALP) were described (Yokel et al., 2005). ${ }^{26} \mathrm{Al}$ was provided by the Purdue Rare Isotope Measurement Laboratory (PRIME Lab), supplied in $0.06 \mathrm{~N} \mathrm{HCl}$ containing $13.78 \mathrm{nCi}$ (725 ng) ${ }^{26} \mathrm{Al} / \mathrm{ml}$ and with a $34: 1{ }^{27} \mathrm{Al}:{ }^{26} \mathrm{Al}$ ratio. Briefly, Al-containing sodium aluminate was prepared then characterized by elemental analysis of $\mathrm{Na}$ and $\mathrm{Al}$ and Raman spectroscopy. It was incorporated into the synthesis of basic SALP (CAS [7785-88-8], INS No. 541) by the method of (Bell, 1973). The basic SALP was characterized by near infrared spectroscopy, $x-$ ray powder diffraction spectroscopy, and elemental analysis of $\mathrm{Na}, \mathrm{Al}$ and $\mathrm{P} .{ }^{26} \mathrm{Al}$-containing basic SALP was concurrently and identically prepared. Non- ${ }^{26} \mathrm{Al}$-containing basic SALP was used to dilute ${ }^{26} \mathrm{Al}$-containing samples to $\sim 1 \mathrm{nCi}{ }^{26} \mathrm{Al} / 15$ or $30 \mathrm{mg}$ basic SALP. The ${ }^{26} \mathrm{Al}-$ basic SALP was incorporated into a process cheese. These two concentrations (1.5 and 3\% basic SALP) were studied to ascertain if there was concentration-dependent absorption and to stay within the maximum permitted use level of 3 to $3.5 \%$ for basic SALP as an emulsifying agent in process cheese. Cheese containing ${ }^{26} \mathrm{Al}$-basic SALP was prepared from $8.8 \mathrm{gm}$ aged 
(1 year) Kroger brand sharp cheddar cheese, $~ 1$ gm water and 150 or $300 \mathrm{mg}$ basic SALP (to make 1.5 and $3 \%$ SALP in cheese). To produce a moderately firm cheese product the ingredients were heated in a microwave oven for $13 \mathrm{sec}$, stirred for $15 \mathrm{sec}$, heated for another $5 \mathrm{sec}$, stirred $10 \mathrm{sec}$ and some samples further heated and stirred. Identical process cheeses were prepared containing 1.5, 2.25 and $3 \%$ SALP without ${ }^{26} \mathrm{Al}$. They were used to condition the rats to eat the process cheese and to dose the control (non- ${ }^{26} \mathrm{Al}$-treated) rats, as described below.

The ${ }^{26} \mathrm{Al}$ concentration in the process cheese was determined as follows. Three samples, $\sim 30$ to $35 \mathrm{mg}$, of the 1.5 and $3 \%{ }^{26} \mathrm{Al}$-basic SALP were transferred to $7 \mathrm{ml}$ screw cap Teflon ${ }^{\circledR}$ Tuftainers $®$ and $4 \mathrm{mg} \mathrm{Al}$ (Sigma ICP/DCP standard) added, and the sample dried. Samples were then digested in $1.5 \mathrm{ml} 1 \mathrm{M} \mathrm{KOH}$ and sonicated to create a solution, as described (Saiyed and Yokel, 2005), serially diluted 10-fold 4 times, and an aliquot transferred to a porcelain crucible and $4 \mathrm{mg}$ of $\mathrm{Al}$ standard added. This was slowly heated to $1000^{\circ} \mathrm{C}$ in a muffle furnace to convert the $\mathrm{Al}$ to $\mathrm{Al}$ oxide that was analyzed by AMS, as described below. The process cheeses containing 1.5 and $3 \%$ basic ${ }^{26} \mathrm{Al}-\mathrm{SALP}$ had $1.80 \mathrm{nCi}(95.0 \mathrm{ng})$ and $1.57 \mathrm{nCi}(82.6$ ng) ${ }^{26} \mathrm{Al} / \mathrm{gm}$, respectively.

\section{Animals}

This study used 15 male Fisher 344 rats, weighing $272 \pm 11$ g (mean \pm SD) that were housed individually prior to the study in the University of Kentucky Division of Laboratory Animal Resources facility. Animal work was approved by the University of Kentucky Institutional Animal Care and Use Committee. The research was conducted in accordance with the Guiding Principles in the Use of Animals in Toxicology.

\section{Experimental procedures}

The rats were acclimated to a $10 \%$ protein diet designed to minimize food retention in the stomach (Harlan Teklad 95215). They had food access from 08:00 to 18:00 h daily for at least 5 days prior to the determination of oral Al bioavailability. This diet was shown to result in the absence of food in the stomach $14 \mathrm{~h}$ after its withdrawal when fecal recycling (coprophagia) was prevented by a fecal collection cup, as described and used in this study (Yokel et al., 2001). Drinking water was freely available throughout the study except for the period from 14 $\mathrm{h}$ before to $4 \mathrm{~h}$ after presentation of cheese containing basic SALP.

The rats were conditioned to eat $1 \mathrm{~g}$ of process cheese containing $1.5 \%$ and 3\% basic SALP (containing no ${ }^{26} \mathrm{Al}$ ) on alternate days which was presented, with access to $2 \mathrm{ml}$ of MilliQ polished water, $14 \mathrm{~h}$ after diet removal daily for at least 4 days. Rats that readily ate the cheese within 15 min were surgically prepared 1 day prior to oral dosing with two venous cannulae introduced into the femoral veins. They terminated in the vena cava. One cannula was used for iv administration, the other for blood withdrawal. The former terminated down-stream of the latter. The amount of cheese containing ${ }^{26} \mathrm{Al}$-basic SALP that was consumed was determined by pre-weighing the presented cheese then rigorously recovering from the rat's cage $30 \mathrm{~min}$ later the uneaten cheese, which was weighed. Calculations were based on the weight of consumed cheese.

The rats were randomly assigned to be given $1 \mathrm{~g}$ process cheese containing 1.5 or $3 \%$ basic ${ }^{26} \mathrm{Al}-\mathrm{SALP}(\mathrm{n}=6 / \mathrm{group}$ ), in the absence of food in the stomach. Three control rats were included to document ${ }^{26} \mathrm{Al}$ contamination. They received process cheese containing $2.25 \%$ basic SALP $(n=2)$ or intragastric administration of $1 \mathrm{ml}$ of water $(n=1)$ without ${ }^{26} \mathrm{Al}$. They served as monitors for ${ }^{26} \mathrm{Al}$ contamination. The rats were studied in pairs that received the same ${ }^{27} \mathrm{Al}$ infusion but different oral treatments. 
Oral Al bioavailability was determined in the un-anesthetized rat. Oral bioavailability was determined using a modification of the standard method of comparing the areas under the concentration $\times$ time curve (AUC). To enable concurrent administration of the oral and iv $\mathrm{Al}$ dose, the tracer ${ }^{26} \mathrm{Al}$ was used as the oral dose and ${ }^{27} \mathrm{Al}$ for the iv dose. To give a large enough bolus iv dose of ${ }^{27} \mathrm{Al}$ that would be significantly above the normal endogenous $\mathrm{Al}$ concentration in serum for a long enough period of time to determine its AUC would require a dose that would exceed the transferrin binding capacity for $\mathrm{Al}(\sim 1350 \mu \mathrm{g} \mathrm{Al} / \mathrm{L})$. Therefore the chemical species of the ${ }^{27} \mathrm{Al}$ in serum would be different (not all Al-transferrin, but for the $\mathrm{Al}$ beyond the transferrin binding capacity probably $\mathrm{Al}$ citrate) and might be handled differently than the ${ }^{26} \mathrm{Al}$ that is absorbed and could bind to transferrin after enough of the ${ }^{27} \mathrm{Al}$ had been cleared to free up binding sites on transferrin. Therefore, we replaced the iv bolus dose with an iv infusion to generate a ${ }^{27} \mathrm{Al}$ serum concentration significantly above the endogenous $\mathrm{Al}$ concentration (so the $\mathrm{Al}$ in the serum could be attributed to the ${ }^{27} \mathrm{Al}$ infusion [iv dose]) but below the transferrin binding capacity. In summary, dose $\mathrm{iv}_{\mathrm{iv}}$ was replaced by ${ }^{27} \mathrm{Al}$ infusion rate $\times{ }^{27} \mathrm{Al}$ infusion duration, as reported in Data analysis.

The rat was iv infused at $100 \mu \mathrm{g}{ }^{27} \mathrm{Al} / \mathrm{kg} / \mathrm{h}$ to produce an estimated $500 \mu \mathrm{g} \mathrm{Al} / \mathrm{l}$ in blood plasma for the ${ }^{27} \mathrm{Al}$ dose, as described (Yokel et al., 2001). To accomplish this in the present study, $\mathrm{AlK}\left(\mathrm{SO}_{4}\right)_{2}$ was infused from $14 \mathrm{~h}$ prior to $60 \mathrm{~h}$ after oral dosing. Blood was withdrawn $1 \mathrm{~h}$ prior to and $0,1,2,4,8,24,36,48$ and $60 \mathrm{~h}$ after oral dosing. The withdrawn blood $(0.3 \mathrm{ml}$ for the -1 to $4 \mathrm{~h}$ samples, $0.5 \mathrm{ml}$ for the $8 \mathrm{~h}$ sample, $2.1 \mathrm{ml}$ at $24 \mathrm{~h}$ and $4.1 \mathrm{ml}$ at $36 \mathrm{and} 48 \mathrm{~h}$ ), was replaced by an equal volume of injected saline. Additionally, the rats had access to free water and food (10\% protein diet) beginning $4 \mathrm{~h}$ after dosing. The 60 -h blood sample was obtained by anesthetizing the rat and exsanguination from a femoral cannula and then the heart. Serum was obtained for ${ }^{26} \mathrm{Al}$ and ${ }^{27} \mathrm{Al}$ analysis. Blood urea nitrogen (BUN) and creatinine were determined in the $60 \mathrm{~h}$ sample.

\section{Analysis of total Al by electrothermal atomic absorption spectrometry (ETAAS)}

This was conducted as described (Yokel and Florence, 2006).

\section{Analysis of ${ }^{26} \mathrm{Al}$ by accelerator mass spectrometry (AMS)}

The procedures were as described (Yokel et al., 2001). A serum QC sample was included with each of the four batches of processed samples. All results were within $10 \%$ of the mean of the 5 initial replicates determined when these QC samples were prepared.

\section{Data analysis}

A criterion for acceptance of post-treatment serum ${ }^{26} \mathrm{Al}$ concentrations considered to be reliably above pre-treatment serum values was established as $>2 \mathrm{SD}$ above the mean pretreatment serum ${ }^{26} \mathrm{Al}$ concentration. This criterion was $0.34 \mathrm{fg}{ }^{26} \mathrm{Al} / \mathrm{ml}$. Values below this criterion are not presented graphically and were not used in the data analysis. This criterion was met by all of the samples from the ${ }^{26} \mathrm{Al}$-treated rats. The initial and $2^{\text {nd }}$ half-lives of ${ }^{26} \mathrm{Al}$ elimination, determined using RSTRIP (Fox and Lamson, 1989), were not different between the two treatment groups, therefore they were combined. The mean initial and $2^{\text {nd }}$ half-lives were 4.4 and $7.2 \mathrm{~h}$, respectively. Therefore, blood was obtained for $>3$ half-lives, sufficient time to determine the AUC of the ${ }^{26} \mathrm{Al}$. Each subject's pre-treatment serum ${ }^{26} \mathrm{Al}$ concentration was subtracted from its post-treatment values. Oral ${ }^{26} \mathrm{Al}$ bioavailability $(\mathrm{F})$ was calculated as follows and expressed as a percent:

$$
\mathrm{F}=\frac{\text { The sum of the trapezoidal areas for }{ }^{26} \mathrm{Al}}{\text { The sum of the trapezoidal areas for }{ }^{27} \mathrm{Al}} \times \frac{{ }^{27} \mathrm{Al} \text { hourly infusion rate } \times \text { time }}{{ }^{26} \mathrm{Al} \text { dose }}
$$


Time to maximum serum ${ }^{26} \mathrm{Al}$ concentration $\left(\mathrm{T}_{\max }\right)$ and the maximum concentration $\left(\mathrm{C}_{\max }\right)$ were calculated using RSTRIP (Fox and Lamson, 1989).

Unpaired two-tailed t-tests (Mann Whitney tests when the variance was dissimilar) were used to test for differences in $\mathrm{Al}$ oral bioavailability, $\mathrm{T}_{\max }$ and $\mathrm{C}_{\max }$ from the $1.5 \%$ compared to $3 \%$ basic SALP. When not statistically significantly different, the combined basic SALP results were compared to acidic SALP in biscuit and water, which were previously conducted (Yokel and Florence, 2006). A difference of $P<0.05$ was accepted as statistically significant.

\section{Results}

The rats given cheese containing ${ }^{26} \mathrm{Al}-\mathrm{SALP}$ consumed 0.44 to $1.05($ mean $=0.87)$ gm cheese. Each rat's serum ${ }^{26} \mathrm{Al}$ results were normalized to its ${ }^{26} \mathrm{Al}$ dose. The $\mathrm{BUN}$ and serum creatinine values ranged from 7.5 to 17.9 and from $<0.2$ to $0.5 \mathrm{mg} / \mathrm{dl}$, well within normal limits $(<30$ and $1 \mathrm{mg} / \mathrm{dl}$, respectively). Serum ${ }^{26} \mathrm{Al}$ concentration in all but one rat prior to ${ }^{26} \mathrm{Al}$ (or ${ }^{26} \mathrm{Al}$ vehicle) dosing ranged from 0 to $0.4($ mean $=0.12) \mathrm{fg} / \mathrm{ml}$. Initial samples from one control rat were contaminated. Its pre-treatment and first 4 post-treatment samples ranged from 0.6 to $12.1 \mathrm{fg}{ }^{26} \mathrm{Al} / \mathrm{ml}$, whereas the $6^{\text {th }}$ to $9^{\text {th }}$ samples from this control rat had 0.1 to $0.2 \mathrm{fg}^{26} \mathrm{Al} / \mathrm{ml}$. Results from this animal have been deleted from the data analysis. The concentration of ${ }^{26} \mathrm{Al}$ in the 8 samples from each of the other two non- ${ }^{26} \mathrm{Al}$-treated rats after vehicle dosing ranged from 0 to $0.5 \mathrm{fg} / \mathrm{ml}$ (mean $=0.18$ ). The 60 hour sample ${ }^{26} \mathrm{Al}$ concentration in the ${ }^{26} \mathrm{Al}$-treated rats ranged from 0.4 to $3.8 \mathrm{fg} / \mathrm{ml}$. Therefore, contamination appears to have been limited to the 5 samples from the one rat.

Peak serum ${ }^{26} \mathrm{Al}$ concentration ranged from 55.9 to $159.5 \mathrm{fg} / \mathrm{ml}$ after oral ${ }^{26} \mathrm{Al}$ dosing in $1.5 \%$ basic SALP and 28.9 to $146.1 \mathrm{fg} / \mathrm{ml}$ after $3 \%$ basic SALP. The oral ${ }^{26} \mathrm{Al}$ dose increased peak serum ${ }^{26} \mathrm{Al}$ at least 200 -fold above mean pre-treatment values. The time courses of serum ${ }^{26} \mathrm{Al}$ following oral ${ }^{26} \mathrm{Al}$ dosing for the two treatment groups are shown in Figure 1. Oral bioavailability (F) was calculated as described in Data analysis as the (sum of ${ }^{26} \mathrm{Al}$ AUC/ sum $\left.{ }^{27} \mathrm{Al} \mathrm{AUC}\right) \times$ the sampling duration $\times{ }^{27} \mathrm{Al}$ hour infusion rate $\times$ body weight $\times 100 \%$. For one of the rats that consumed cheese containing $1.5 \%$ SALP F was $0.12 \%$, calculated from ((the sum of the trapezoidal AUCs for ${ }^{26} \mathrm{Al}$ [each area calculated as the mean of the ${ }^{26} \mathrm{Al}$ concentration in the two samples, in $\mathrm{fg} / \mathrm{ml} \times$ the trapezoidal time interval, in $\mathrm{hr}] / \mathrm{sum}$ of trapezoidal AUCs for ${ }^{27} \mathrm{Al}$ [each area calculated as the mean of the ${ }^{27} \mathrm{Al}$ concentration in the two samples, in $\mathrm{fg} / \mathrm{ml}] \times$ the trapezoidal time interval, in $\mathrm{hr}) \times(($ the total duration of the serum sampling period, in $\mathrm{hr} \times$ the ${ }^{27} \mathrm{Al}$ infusion rate, in $\mathrm{fg} / \mathrm{kg} / \mathrm{hr} \times$ the rat's body wt, in $\left.\mathrm{kg}\right) /(52630000$ $\times \mathrm{nCi}^{26} \mathrm{Al} / \mathrm{gm}$ cheese $\times$ gm cheese consumed by the rat))) $\times 100$, where the sum of the ${ }^{26} \mathrm{Al}$ AUCs was $2013 \mathrm{fg} / \mathrm{ml} / \mathrm{hr}$, the sum of the ${ }^{27} \mathrm{Al}$ AUCs was $25728 \mathrm{ng} / \mathrm{ml} / \mathrm{hr}$, the ${ }^{27} \mathrm{Al}$ infusion rate was $100000000000 \mathrm{fg} / \mathrm{kg} / \mathrm{hr}$, the rat's body weight was $0.254 \mathrm{~kg}, 52630000$ converts $\mathrm{nCi}^{26} \mathrm{Al}$ to $\mathrm{fg}{ }^{26} \mathrm{Al}$, the cheese had $1.804 \mathrm{nCi}{ }^{26} \mathrm{Al} / \mathrm{gm}$, the rat consumed $0.97 \mathrm{gm}$ cheese, and 100 converts to percent.

The percentage of the AUC included in the $\mathrm{AUC}_{\text {time to last sample }} / \mathrm{AUC}_{\text {infinity }}$ was $>95 \%$ in all cases, indicating that samples were collected for sufficient time to adequately determine oral $\mathrm{Al}$ absorption. Oral $\mathrm{Al}$ bioavailability and the results of RSTRIP analyses $\left(\mathrm{T}_{\max }\right.$ and $\left.\mathrm{C}_{\max }\right)$ are shown in Table 1 . Oral bioavailability was marginally significantly different $(P=0.045)$ between the two groups. Therefore, the results from both treatment groups were compared to results obtained in oral bioavailability studies of $\mathrm{Al}$ in water and as acidic SALP in biscuit (Table 1). The differences in sum AUC ${ }^{26} \mathrm{Al}$, sum $\mathrm{AUC}{ }^{27} \mathrm{Al}, \mathrm{Al} \mathrm{T}_{\max }, \mathrm{C}_{\max }$, and $\mathrm{C}_{\max } \%$ dose/ $\mathrm{ml}$ serum results from rats consuming $1.5 \%$ compared to $3 \%$ basic SALP were not statistically significant. Therefore, the differences in these measures from the combined $1.5 \%$ and $3 \%$ basic SALP data were compared to results from studies of $\mathrm{Al}$ absorption from water and as acidic SALP in biscuit (Table 1). 


\section{Discussion}

The present study found a marginally significant effect of the Al concentration on $\mathrm{Al}$ bioavailability, for the two concentrations of basic SALP tested, which are in the range of those permitted by the FDA. The difference between the oral bioavailability of the two groups that received $1.5 \%$ and $3 \%$ basic SALP in cheese was due to the differences in their serum total $\mathrm{Al}$ concentration $\times$ time profiles (as shown in Table 1, Sum AUC for iv ${ }^{27} \mathrm{Al}$ ) rather than their serum ${ }^{26} \mathrm{Al}$ concentration $\times$ time profiles (as shown in Table 1, Sum AUC for po ${ }^{26} \mathrm{Al}$ and Figure 1). As rats were studied in pairs, errors in the ${ }^{27} \mathrm{Al}$ infusion should be reflected in both rats of the pair. This was not seen. We assume that the 3 rats in the group that ate $1.5 \%$ basic SALP in cheese that had higher than average serum ${ }^{27} \mathrm{Al}$, and therefore AUCs for iv ${ }^{27} \mathrm{Al}$, renally cleared the ${ }^{27} \mathrm{Al}$ infusion more slowly than most rats. It would be anticipated that the clearance of ${ }^{26} \mathrm{Al}$ would be similar, concomitantly increasing the AUC for ${ }^{26} \mathrm{Al}$. Therefore, these results seem valid. Had the serum ${ }^{27} \mathrm{Al}$ concentrations in these rats been lower and ${ }^{26} \mathrm{Al}$ concentrations not different, oral Al bioavailability would have been higher. Therefore, the oral bioavailability of $\mathrm{Al}$ from basic SALP incorporated into cheese in the rat appears to be at least $0.1 \%$.

The few studies conducted to date to address the possibility that Al bioavailability is dosedependent have also not resulted in robust findings. Oral Al bioavailability from Al lactate in the rabbit dosed with 108 or $540 \mathrm{mg} \mathrm{Al} / \mathrm{kg}$, as $\mathrm{Al}$ lactate, was 0.7 and $1.9 \%$, although not significantly different (Yokel and McNamara, 1985). Urinary ${ }^{26} \mathrm{Al}$ excretion was higher in two rats after administration of $20 \mathrm{ng}$ of ${ }^{26} \mathrm{Al}$ with $10 \mathrm{mg}{ }^{27} \mathrm{Al}$ than with $0.2 \mathrm{mg}{ }^{27} \mathrm{Al}$ as the chloride (0.032 vs. $0.018 \%$ of the ${ }^{26} \mathrm{Al}$ dose). Serum ${ }^{26} \mathrm{Al}$ was also higher 1,5 and 24 hours after the larger total Al dose (Ittel et al., 1993). These results suggest a positive correlation between aluminium dose and bioavailability. On the other hand, $\mathrm{Al}$ absorption into rat blood and tissues after perfusion of the gut with 48 or $64 \mathrm{mM} \mathrm{Al}$ chloride at $\mathrm{pH} 3$ was not concentration dependent (Arnich et al., 2004).

The later $\mathrm{T}_{\max }$ of $\mathrm{Al}$ from basic SALP in process cheese observed in the present study, compared to water, is consistent with the apparent site of $\mathrm{Al}$ absorption, the upper intestine and delayed gastric emptying of food compared to water (Froment et al., 1989; Nagy and Jobst, 1994; Whitehead et al., 1997; Arnich et al., 2004). $C_{\max }$ values were lower after oral consumption of ${ }^{26} \mathrm{Al}$ in process cheese than water, as expected when oral bioavailability is lower and $\mathrm{T}_{\max }$ is later.

The FDA acceptance of basic SALP as a food additive is based on a review conducted in 1975 (FASEB, 1975). The reviewers cited unpublished studies that demonstrated a consistent increase in renal microconcretions in female, but not male, rats consuming a diet containing 0.03 to $3 \%$ basic SALP ( 4 to $40 \mathrm{mg} \mathrm{Al} / \mathrm{kg} /$ day) for 90 days and an in-consistent increase of this endpoint in male and female beagle dogs that consumed basic SALP delivering 7 to 70 $\mathrm{mg} \mathrm{Al} / \mathrm{kg} / \mathrm{day}$. The review panel noted that care should be taken by patients with kidney disease when consuming food containing high levels of $\mathrm{Al}$ salts. However, they did not mention dialysis encephalopathy, which has been attributed to $\mathrm{Al}$, or the controversial role of $\mathrm{Al}$ in $\mathrm{AD}$. Description of these clinical problems began about 1975. Since that review the contribution of $\mathrm{Al}$ from $\mathrm{Al}$ cooking utensils to serum $\mathrm{Al}$ and urinary $\mathrm{Al}$ excretion in patients with chronic renal insufficiency was demonstrated (Lin et al., 1997) and numerous studies have described toxic endpoints of Al exposure (Krewski et al., 2007).

Some studies have been conducted to assess potential toxicity from basic SALP. A study was conducted by Stauffer Chemical Company in male rats fed their basic SALP-containing products. The treatment groups ate feed for 28 days containing: 3\% KASAL (1866 mg Al/kg diet; daily dose $141 \mathrm{mg} / \mathrm{kg}$ bw), 0.7\% KASAL II (908 mg Al/kg diet; daily dose $67 \mathrm{mg} \mathrm{Al} /$ 
$\mathrm{kg}$ bw), 30,000 ppm KASAL II (3761 mg Al/kg diet; daily dose $288 \mathrm{mg} \mathrm{Al} / \mathrm{kg}$ bw), 14,470 ppm Al hydroxide as a positive control (4034 mg Al/kg diet; daily dose $302 \mathrm{mg} \mathrm{Al} / \mathrm{kg} \mathrm{bw}$ ), or the basic (control) diet (66 mg Al/kg diet; daily dose $5 \mathrm{mg} \mathrm{Al} / \mathrm{kg} \mathrm{bw}$ ) (Hicks et al., 1987). Other than a significant increase of serum sodium, no significant effects were seen in bone $\mathrm{Al}$, gross autopsy, histopathology, food consumption, hematology, clinical chemistry or organ weight. A study was conducted in dogs fed diets containing KASAL that produced daily mean $\mathrm{Al}$ intakes of $\sim 10,25$, or $78 \mathrm{mg} \mathrm{Al} / \mathrm{kg}$ for 26 weeks, compared to a control diet delivering $\sim 4 \mathrm{mg} \mathrm{Al} / \mathrm{kg} /$ day (Pettersen et al., 1990). The highest dose of Kasal resulted in a sharp, 1.5 week decrease in food consumption and body weight in males, a decrease in testis weight, seminiferous tubule germinal cell degeneration and atrophy, hepatocyte vacuolation, and tubular-glomerularnephritis. There were no significant effects on serum chemistry, hematology, urinalysis or bone or brain $\mathrm{Al}$, except for a significant increase of brain $\mathrm{Al}$ in female dogs consuming the highest $\mathrm{Al}$ containing diet. Neither of these studies addressed bioavailability.

There have been studies to estimate oral Al bioavailability from foods. A project was commissioned to determine the relative uptake of Al in many foods (UK-MAFF, 1993). However, the methods did not enable determination of bioavailability and the trial foods did not contain cheese (UK-MAFF, 1993). Al bioavailability from diets containing $\sim 5 \mathrm{mg}$ Al daily was estimated, based on urinary $\mathrm{Al}$ excretion compared to dietary $\mathrm{Al}$ intake, to be $0.78 \%$ in young human males (Greger and Baier, 1983). However, cheese was not included in this study nor in a study by (Stauber et al., 1999) who estimated Al bioavailability from drinking water and food in humans to be comparable from these two sources, $\sim 0.3 \%$. Oral Al bioavailability from food has been estimated to be $\sim 0.1 \%$ based on average daily urinary Al excretion compared to average daily $\mathrm{Al}$ intake from food (Powell and Thompson, 1993; Priest, 1993; Nieboer et al., 1995). The only reported study that determined the bioavailability of Al from a specific food used similar methods to the study reported herein and found it to be $\sim 0.1 \%$ from acidic SALP incorporated into biscuit (Yokel and Florence, 2006).

In summary, the present estimate of oral $\mathrm{Al}$ bioavailability from a dietary component suggests modestly lower or comparable oral Al bioavailability from food than previously reported in studies of water, conducted in the human and rat (Introduction). The results of this study of oral Al bioavailability from basic SALP in a process cheese suggest $\sim 0.1$ to $0.3 \%$ of the $\mathrm{Al}$ was orally absorbed. A prior study and a recent replication of that study, using the same methods (Yokel et al., 2001; Zhou and Yokel, 2006), suggested 0.3\% of Al was orally absorbed from water. Other substances in drinking water might alter Al. For example, citrate doubled $\mathrm{Al}$ absorption from water (Zhou et al., 2008). A comparison of the arithmetic products of the absorbed percentage of $\mathrm{Al}$ times their contribution to the diet suggests food typically provides at least $90 \%$ of dietary $\mathrm{Al}$ that reaches systemic circulation. This is based on consumption of 5 to $10 \mathrm{mg}$ of $\mathrm{Al}$ in the diet $\times 0.1$ to $0.3 \%$ absorption, delivering 5 to $30 \mu \mathrm{g}$ of Al to systemic circulation daily $v s$. consumption of $0.1 \mathrm{mg}$ Al daily in drinking water $\times$ up to $0.6 \%$ absorption, delivering up to $0.6 \mu \mathrm{g}$ of $\mathrm{Al}$ to systemic circulation daily. These results suggesting food is a more important source of absorbed $\mathrm{Al}$ than is drinking water, as noted in the Introduction. This suggests that further study of a potential link between orally consumed $\mathrm{Al}$ in food and cognitive deficits may be more appropriate than studies of $\mathrm{Al}$ in drinking water.

\section{Acknowledgement}

This work was supported by NIH Grant R01 ES11305.

\section{References}

Alfrey AC, LeGendre GR, Kaehny WD. The dialysis encephalopathy syndrome. Possible aluminum intoxication. NEJM 1976;294:184-188. [PubMed: 1244532] 
Arnich N, Cunat L, Lanhers MC, Burnel D. Comparative in situ study of the intestinal absorption of aluminum, manganese, nickel, and lead in rats. Biol. Trace Elem. Res 2004;99:157-171. [PubMed: 15235150]

ATSDR. Toxicological profile for aluminum. Atlanta, GA: Agency for toxic substances and disease registry; $1999.257 \mathrm{p}$.

Bauer, LA. Clinical pharmacokinetics handbook. New York: McGraw-Hill, Medical Pub. Division; 2006. p. 16

Bell, RN. US Patent. NY: Assigned to Stauffer Chemical Company; 1973. Sodium aluminum phosphate cheese emulsifying agent.

Cogbill EC, Hobbs ME. Transfer of metallic constituents of cigarettes to the main-stream smoke. Tobacco Science 1957;1:68-73.

Delves, HT.; Suchak, B.; Fellows, CS. The determination of aluminium in foods and biological materials. In: Massey, R.; Taylor, D., editors. Aluminium in food and the environment. The proceedings of a symposium organized by the Environment and Food Chemistry Groups of the Industrial Division of the Royal Society of Chemistry, Special Publication No.73. London: The Royal Society of Chemistry, Thomas Graham House; 1989. p. 52-67.

Dolan SP, Capar SG. Multi-element analysis of food by microwave digestion and inductively coupled plasma-atomic emission spectrometry. J. Food Comp. Analysis 2002;15:593-615.

Elinder C-G, Ahrengart L, Lidums V, Pettersson E, Sjögren B. Evidence of aluminium accumulation in aluminium welders. Br. J. Ind. Med 1991;48:735-738. [PubMed: 1954151]

Ellinger, RH. Phosphates as food ingredients. Cleveland, OH: CRC Press; 1972. p. 73

Exley C, Begum A, Woolley MP, Bloor RN. Aluminum in tobacco and cannabis and smoking-related disease. Am. J. Med 2006;119:276 e9-276 e11. [PubMed: 16490479]

Exley C, Ahmed U, Polwart A, Bloor RN. Elevated urinary aluminium in current and past users of illicit heroin. Addiction Biol 2007;12:197-199.

FAO/WHO. Summary and conclusions of the sixty-seventh meeting of the Joint FAO/WHO Expert Committee on Food Additives (JECFA), Sixty-seventh meeting in Rome; 20-29 June 2006; 2006. issued 7 July, 2006 http://www.who.int/ipcs/food/jecfa/jecfa67_call\%20final.pdf

FASEB, (Federation of American Societies for Experimental Biology); Life Sciences Research Office. Evaluation of the health aspects of aluminum compounds as food ingredients. Prepared for Bureau of Foods, Food and Drug Administration, Contract No. FDA 223-75-2004, U.S. FDA Report FDA/ BF-77/24, NTIS-PB 262 655, 26 pages. 1975.

Fox, JL.; Lamson, ML. RSTRIP: pharmacokinetic data stripping/least squares parameter optimization. Salt Lake City, UT: MicroMath, Inc.; 1989.

Friesen MS, Purssell RA, Gair RD. Aluminum toxicity following IV use of oral methadone solution. Clin. Toxicol. (Phila) 2006;44:307-314. [PubMed: 16749550]

Froment DP, Molitoris BA, Buddington B, Miller N, Alfrey AC. Site and mechanism of enhanced gastrointestinal absorption of aluminum by citrate. Kidney Int 1989;36:978-984. [PubMed: 2601265]

Gies WJ. Some objections to the use of alum baking-powder. JAMA 1911;57:816-821.

Gormican A. Inorganic elements in foods used in hospital menus. J. Am. Diet. Assoc 1970;56:397-403. [PubMed: 5439980]

Greger JL. Aluminum content of the American diet. Food Technol 1985;39:73-80.

Greger JL, Baier MJ. Excretion and retention of low or moderate levels of aluminium by human subjects. Food Chem. Toxicol 1983;21:473-477. [PubMed: 6684629]

Hicks JS, Hackett DS, Sprague GL. Toxicity and aluminium concentration in bone following dietary administration of two sodium aluminium phosphate formulations in rats. Food Chem. Toxicol 1987;25:533-538. [PubMed: 3623343]

Hohl C, Gerisch P, Korschinek G, Nolte E, Ittel TH. Medical application of ${ }^{26}$ Al. Nucl. Instr. Meth. Phys. Res. Ser. B 1994;92:478-482.

Humphreys, S.; Bolger, PM. A public health analysis of dietary aluminium. In: Zatta, PF.; Alfrey, AC., editors. Aluminium toxicity in infants' health and disease. Singapore: World Scientific, Singapore; 1997. p. 226-237. 
Ittel TH, Gerisch P, Nolte E, Sieberth HG. Fractional absorption of aluminium is dose-dependent: A ${ }^{26}$ Al tracer study. Nephrol. Dial Transplant 1993;8:993.(An abstract)

Katz AC, Frank DW, Sauerhoff MW, Zwicker GM, Freudenthal RI. A 6-month dietary toxicity study of acidic sodium aluminium phosphate in beagle dogs. Food Chem. Toxicol 1984;22:7-9. [PubMed: 6537941]

Krewski D, Yokel RA, Nieboer E, Borchelt D, Cohen J, Harry J, Kacew S, Lindsay J, Mahfouz AM, Rondeau V. Human health risk assessment for aluminium, aluminium oxide, and aluminium hydroxide. J. Toxicol. Environ. Health, Part B: Critical Reviews 2007;10:1-269.

Lin JL, Yang YJ, Yang SS, Leu ML. Aluminum utensils contribute to aluminum accumulation in patients with renal disease. Am. J. Kid. Disease 1997;30:653-658. [PubMed: 9370180]

Lopez FE, Cabrera C, Lorenzo ML, Lopez MC. Aluminum levels in convenience and fast foods: in vitro study of the absorbable fraction. Sci. Total Environ 2002;300:69-79. [PubMed: 12685472]

Martyn CN, Barker DJ, Osmond C, Harris EC, Edwardson JA, Lacey RF. Geographical relation between Alzheimer's disease and aluminum in drinking water. Lancet 1989;i:59-62. [PubMed: 2562879]

Müller M, Anke M, Illing-Günther H. Aluminium in foodstuffs. Food Chem 1998;61:419-428.

Nagy E, Jobst K. The kinetics of aluminium-containing antacid absorption in man. Eur. J. Clin. Chem. Clin. Biochem 1994;32:119-121. [PubMed: 8031961]

Nieboer E, Gibson BL, Oxman AD, Kramer JR. Health effects of aluminum: a critical review with emphasis on aluminum in drinking water. Environ. Rev 1995;3:29-81.

Pennington, JA. Dietary intake of aluminum. In: Gitelman, HJ., editor. Aluminum and health: A critical review. New York: Marcel Dekker, Inc.; 1989. p. 67-100.

Pennington JA, Schoen SA. Estimates of dietary exposure to aluminium. Food Addit. Contam 1995;12:119-128. [PubMed: 7758626]

Pennington JAT. Aluminium content of foods and diets. Food Addit. Contam 1987;5:161-232. [PubMed: 3360205]

Pettersen JC, Hackett DS, Zwicker GM, Sprague GL. Twenty-six week toxicity study with KASAL® (basic sodium aluminum phosphate) in beagle dogs. Environ. Geochem. Health 1990;12:121-123.

Phelps KR, Naylor K, Brien TP, Wilbur H, Haqqie SS. Encephalopathy after bladder irrigation with alum: case report and literature review. American journal of medicine 1999;318:181-185.

Powell JJ, Thompson RP. The chemistry of aluminium in the gastrointestinal lumen and its uptake and absorption. Proc. Nutr. Soc 1993;52:241-253. [PubMed: 8493270]

Priest ND. The bioavailability and metabolism of aluminium compounds in man. Proc. Nutr. Soc 1993;52:231-240. [PubMed: 8493269]

Priest ND, Talbot RJ, Newton D, Day JP, King SJ, Fifield LK. Uptake by man of aluminium in a public water supply. Hum. Exp. Toxicol 1998;17:296-301. [PubMed: 9688351]

Rogers MAM, Simon DG. A preliminary study of dietary aluminium intake and risk of Alzheimer's disease. Age and Ageing 1999;28:205-209. [PubMed: 10350420]

Saiyed SM, Yokel RA. Aluminium content of some foods and food products in the USA, with aluminium food additives. Food Addit. Contam 2005;22:234-244. [PubMed: 16019791]

Schenk, RU.; Bjorksten, J.; Yeager, L. Composition and consequences of aluminum in water, beverages and other ingestibles. In: Lewis, TE., editor. Environmental chemistry and toxicology of aluminum. Chelsea, MI: Lewis Publishers; 1989. p. 247-269.

Stauber JL, Florence TM, Davies CM, Adams MS, Buchanan SJ. Bioavailability of Al in alum-treated drinking water. Journal AWWA (American Water Works Association) 1999;91:84-93.

Talbot R, Newton D, Priest N, Austin J, Day J. Inter-subject variability in the metabolism of aluminium following intravenous injection as citrate. Hum Exp Toxicol 1995;14:595-599. [PubMed: 7576820]

UK-MAFF (United Kingdom Ministry of Agriculture Fisheries and Food). Aluminium in food. The thirty ninth report of the Steering Group on Chemical Aspects of Food Surveillance. Food Surveillance Paper No. 39. In $48+3$ appendices. London: HMSO (Her Magesty's Stationery Office); 1993.

Whitehead MW, Farrar G, Christie GL, Blair JA, Thompson RP, Powell JJ. Mechanisms of aluminum absorption in rats. Am. J. Clin. Nutr 1997;65:1446-1452. [PubMed: 9129475]

WHO. Environmental Health Criteria 194. Geneva: World Health Organization; 1997. International Programme on chemical safety, Aluminium. 
Yokel RA, Florence RL. Aluminum bioavailability from the approved food additive leavening agent acidic sodium aluminum phosphate, incorporated into a baked good, is lower than from water. Toxicology 2006;227:86-93. [PubMed: 16949191]

Yokel RA, McNamara PJ. Aluminum bioavailability and disposition in adult and immature rabbits. Toxicol. Appl. Pharmacol 1985;77:344-352. [PubMed: 3975904]

Yokel RA, McNamara PJ. Aluminum toxicokinetics: An updated mini-review. Pharmacol. Toxicol 2001;88:159-167. [PubMed: 11322172]

Yokel RA, Rhineheimer SS, Brauer RD, Sharma P, Elmore D, McNamara PJ. Aluminum bioavailability from drinking water is very low and is not appreciably influenced by stomach contents or water hardness. Toxicology 2001;161:93-101. [PubMed: 11295258]

Yokel RA, Urbas AA, Lodder RA, Selegue JP, Florence RL. ${ }^{26}$ Al-containing acidic and basic sodium aluminum phosphate preparation and use in studies of oral aluminum bioavailability from foods utilizing ${ }^{26} \mathrm{Al}$ as an aluminum tracer. Nucl. Instr. Meth. Physics Res. Sec. B 2005;229:471-478.

Yong RL, Holmes DT, Sreenivasan GM. Aluminum toxicity due to intravenous injection of boiled methadone. NEJM 2006;354:1210-1211. [PubMed: 16540630]

Zhou, Y.; Yokel, RA. The effect of citrate, maltolate and fluoride on oral ${ }^{26} \mathrm{Al}$ absorption. J. Inorganic Biochem. 2006. http://dx.doi.org/10.1016/j.jinorgbio.2007.11.019

\section{Abbreviations}

AD, Alzheimer's disease

$\mathrm{Al}$, aluminum

AMS, accelerator mass spectrometry

AUC, area under the (concentration $\mathrm{x}$ time) curve

$\mathrm{C}_{\max }$, maximum serum concentration

ETAAS, electrothermal atomic absorption spectrometry

F, oral bioavailability

GRAS, generally recognized as safe

PTWI, provisional tolerable weekly intake

SALP, sodium aluminum phosphate

$\mathrm{T}_{\max }$, time to maximum serum concentration 


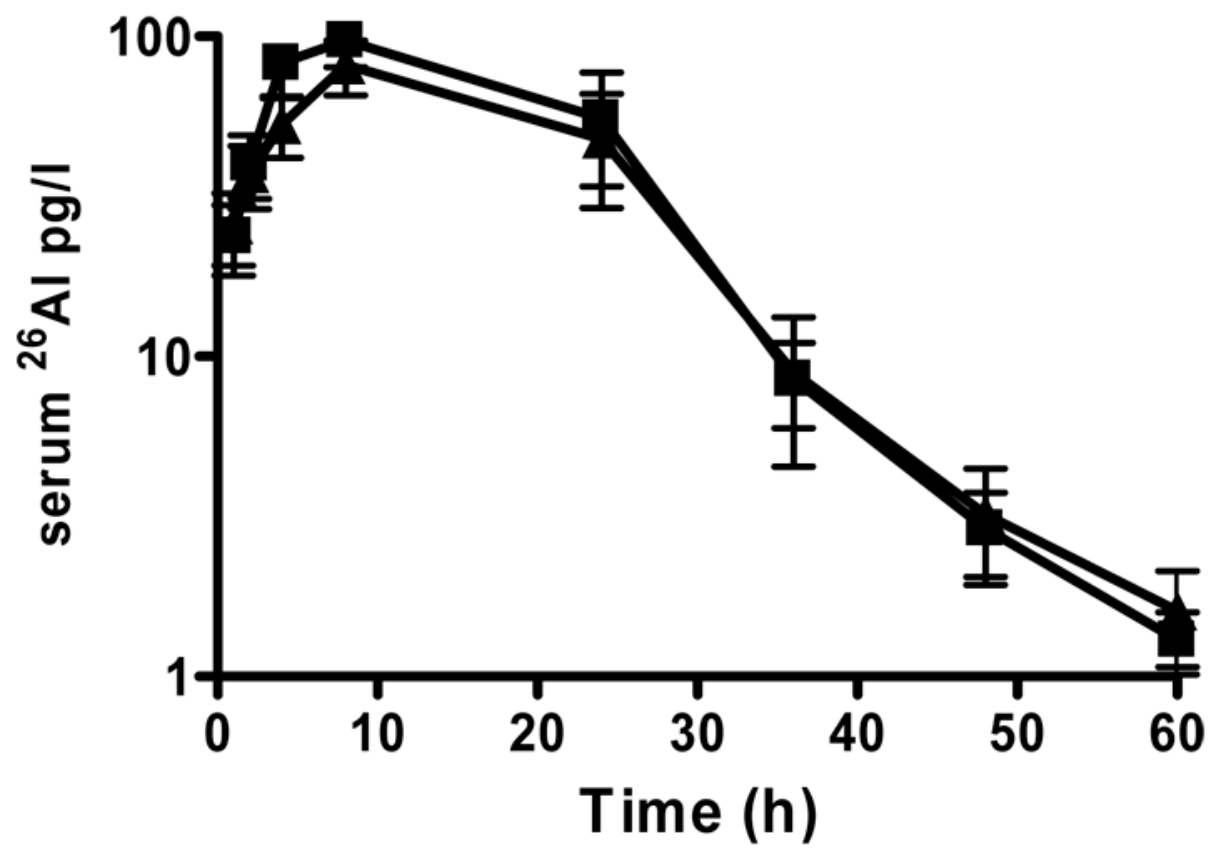

Figure 1.

Concentration of ${ }^{26} \mathrm{Al}$ in serum versus time after consumption of basic ${ }^{26} \mathrm{Al}-\mathrm{SALP}$ in a process cheese containing $1.5 \%$ (square) or $3 \%$ (triangle) basic SALP. The values are mean \pm SD from 6 rats in each group. 
Table 1

The results of major determinates of oral Al bioavailability, the oral bioavailability of Al, and other pharmacokinetic parameters in rats dosed with 1.5 or $3 \%$ basic SALP, containing ${ }^{26} \mathrm{Al}$, in cheese (this study) and prior studies with acidic SALP in biscuit or in water. Values are mean \pm SD.

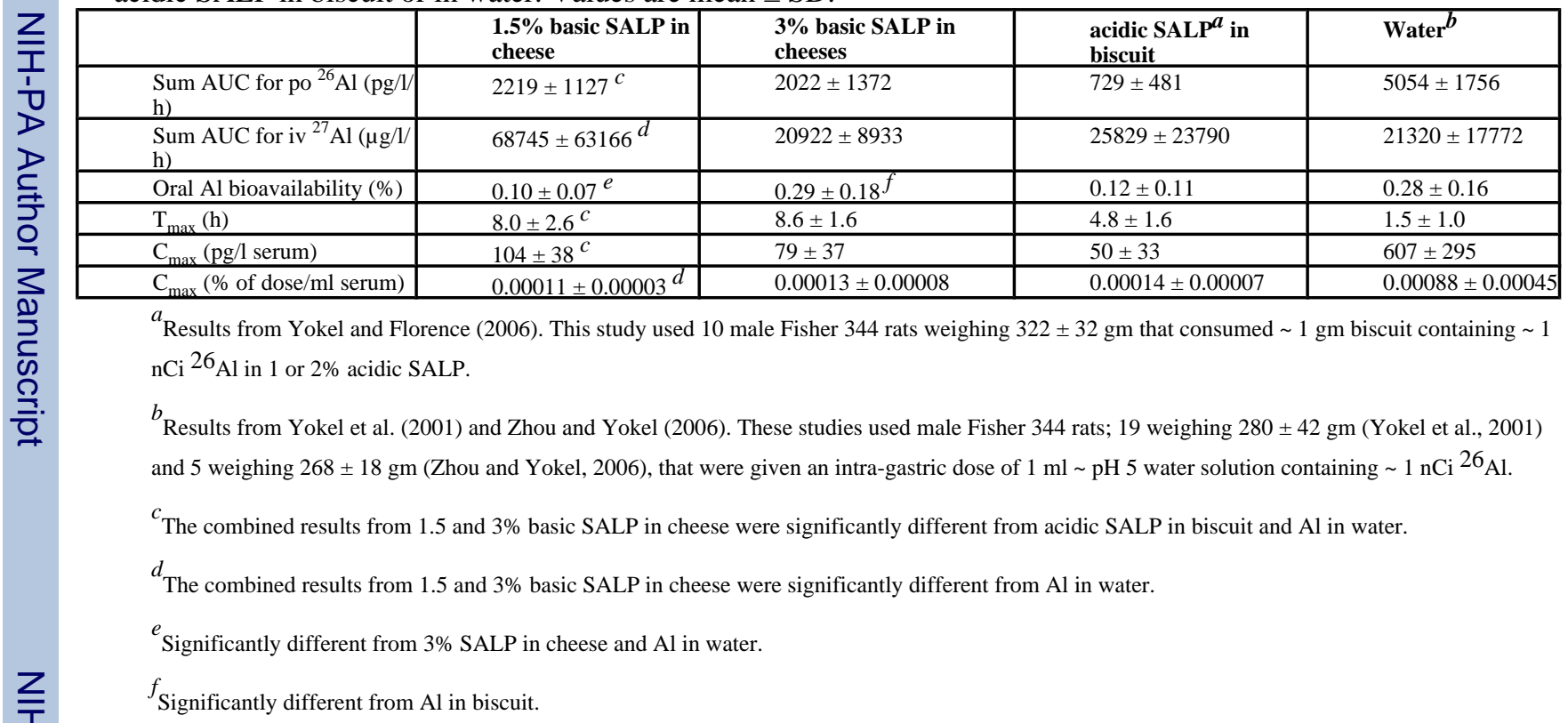

